\title{
Nucleolar organiser regions in fibrous proliferations of childhood and infantile fibrosarcoma
}

\author{
M J EGAN, F RAAFAT, J CROCKER, * K SMITH \\ From the Departments of Histopathology, Birmingham Children's Hospital, Ladywood Middleway, and *East \\ Birmingham Hospital, Bordesley Green East, Birmingham
}

SUMMARY A silver colloid technique to identify nucleolar organiser region associated protein (AgNOR) was applied to 16 fibrous proliferations of childhood and six low grade fibrosarcomas. The fibrous proliferations comprised five cases of infantile digital fibromatosis, seven of infantile desmoid type fibromatosis, and four of infantile myofibromatosis. The AgNORs were visualised as dots within the nuclei of the cells, and on the basis of their relative mean numbers of AgNORs fibrous proliferations of childhood could be easily differentiated from low grade infantile fibrosarcoma. The differences observed were significant $(0.01>p>0.001)$. This technique, previously the province of the cytogeneticist, may be of use to the pathologist in differentiating infantile fibrous proliferations.

Fibrous proliferations of childhood can be divided into two large groups: lesions corresponding in clinical signs and symptoms, microscopy, and behaviour to similar lesions occurring in adults-for example, the desmoid tumour; and fibrous lesions peculiar to infancy and childhood that have no counterpart in adult life. This second group poses a special diagnostic problem as the microscopic picture often fails to reflect behaviour, and features such as cellularity may be mistaken for evidence of malignancy and this sometimes leads to unneccessary and excessive treatment.

Accurate diagnosis and interpretation of these lesions is therefore of the utmost importance and we decided to apply the relatively new silver colloid technique for nucleolar organiser region associated proteins (AgNORs) to try to facilitate diagnosis.

\section{Material and methods}

Sixteen specimens of fibrous proliferations of childhood and six cases of infantile well differentiated fibrosarcoma were examined. The fibrous proliferations included five cases of infantile digital fibromatosis, seven cases of infantile desmoid type fibromatosis, and four cases of infantile myofibromatosis. Each specimen, taken from a separate patient, had been previously characterised by a combination of light and electron microscopy.

Accepted for publication 21 July 1987
Sections $(3 \mu \mathrm{m})$ of routinely processed, formalin fixed, paraffin embedded blocks were cut, dewaxed in xylene, and hydrated through ethanols to deionised distilled water. The silver colloid solution for staining of AgNORs was prepared by dissolving gelatin in $1 \%$ aqueous formic acid at a concentration of $2 \%$; this solution was mixed $1 / 2$ volumes, with $50 \%$ aqueous silver nitrate to obtain the final working solution. This was dropped on to the sections and left for 60 minutes at room temperature under safelight conditions after which the sections were washed with deionised water and counterstained with Mayer's haemalum. The sections were taken to xylene and mounted in a synthetic medium. The usual controls were performed as previously described.'

The AgNORs were seen as dots within the nuclei of the cells in each case. Previous pilot studies had shown that 200 cell samples were representative and 200 cells were examined from randomly selected fields using a $\times 100$ oil immersion lens. The mean number of AgNORs per cell was then calculated. The inter- and intraobserver error was found to be between $1 \%$ and $2 \%$.

\section{Results}

The various types of fibrous proliferations of infancy could not be distinguished on the basis of their relative numbers of AgNORs. Overall, the mean number of AgNORs was 3.7 and the range 2.7-5.9. The dots or blebs were almost totally confined to the nucleoli of 
the cells (fig 1). By contrast, low grade fibrosarcoma had a mean number of $11.5 \mathrm{AgNORs}$ with a range of 10.0-13.0. The AgNORs were not only confined to nucleoli, but were widely distributed in the nuclei

(fig 2).

Student's $t$ test was used to differentiate between the two groups: $t$ was equal to 15.18 and $\mathrm{p}=0.01-0.001$. The results are summarised in fig 3 .

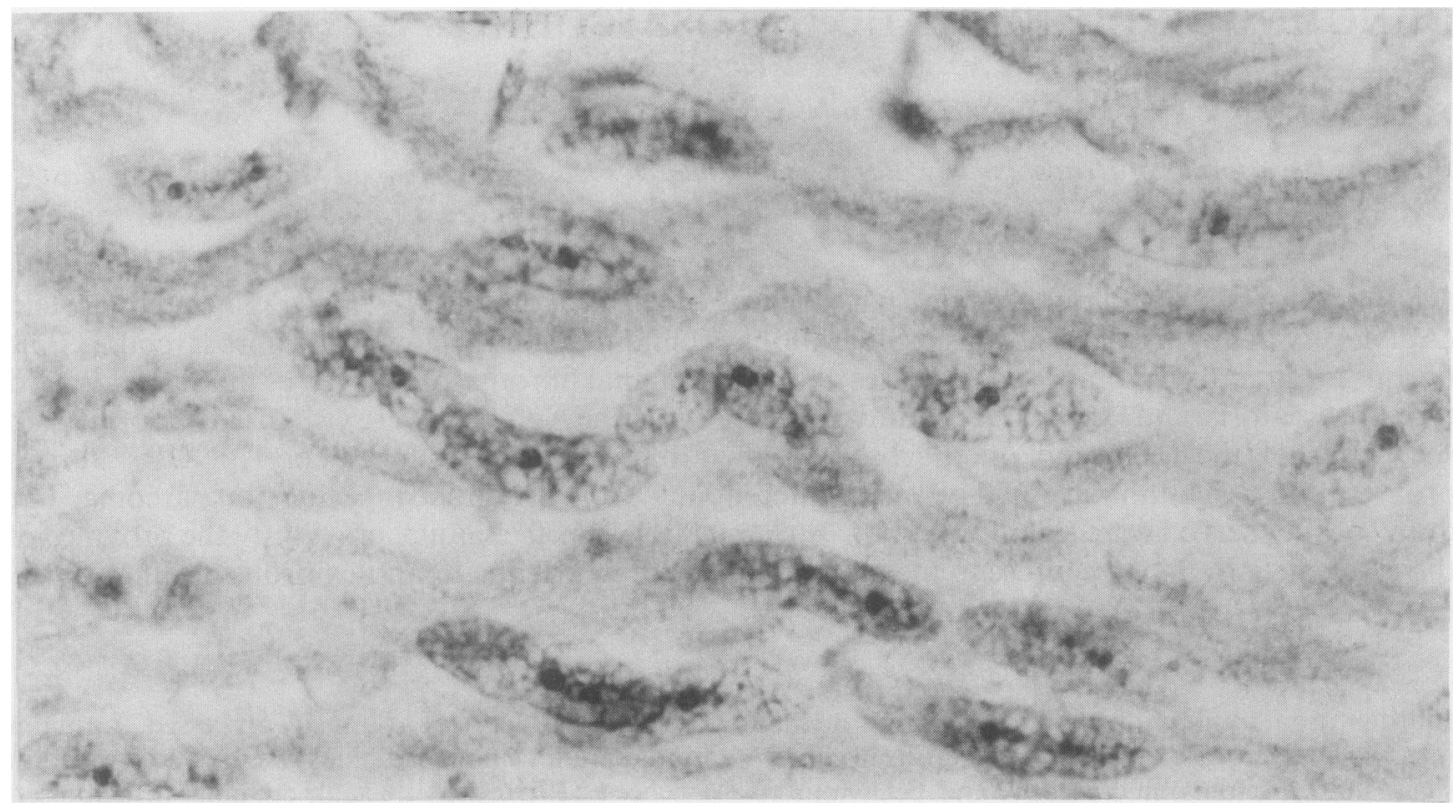

Fig 1 Infantile desmoid type fibromatosis stained with silver colloid technique for AgNORs. Several AgNORs are seen, localised almost exclusively in nucleoli.

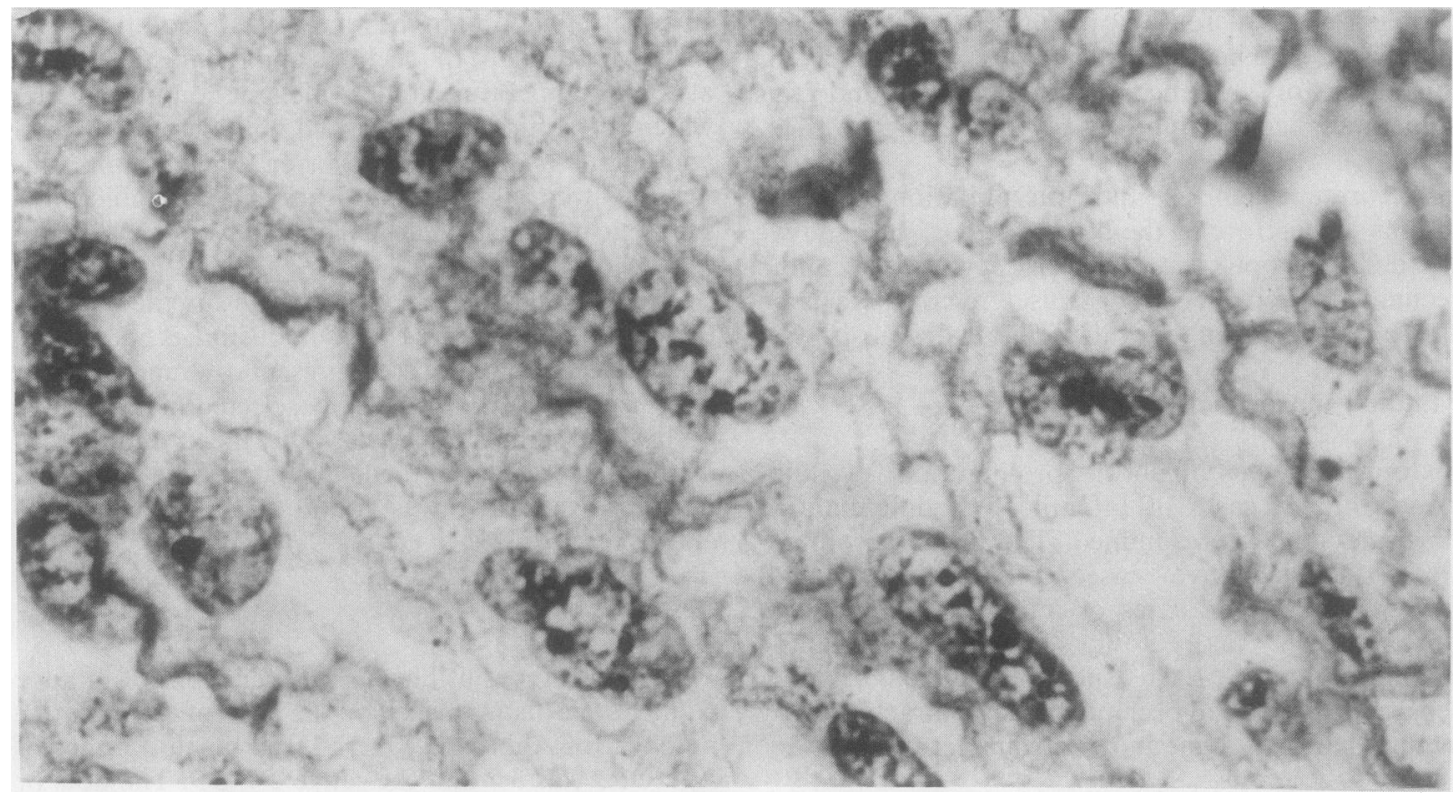

Fig 2 Low grade fibrosarcoma stained with silver colloid technique for AgNORs. Numerous AgNORs are seen in nuclei. 


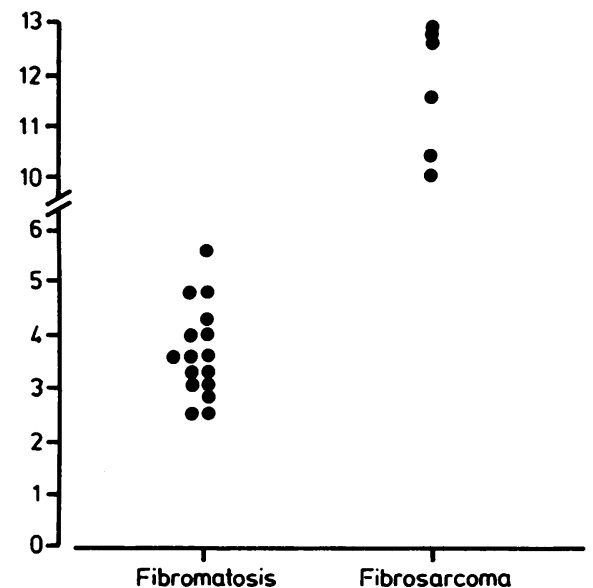

Fig 3 Scattergram to show mean numbers of AgNORs for each case of fibromatosis and fibrosarcoma. There is a clearly defined and significant difference between low grade fibrosarcoma and fibrous proliferations of childhood ( $p=$ $0.01-0.001)$.

\section{Discussion}

AgNORs are loops of DNA occurring in the nuclei of cells that possess ribosomal RNA (rRNA) genes. In man five chromosomes have AgNORs and these areas are the sites which hybridise with rRNA and are important in the ultimate synthesis of protein. ${ }^{1}$ The molecules thought to be associated with AgNORs include RNA polymerase itself, C23 protein, and a molecule similar to $\mathrm{C} 23$ protein but with a smaller molecular size ( $100 \mathrm{kD}$ compared with $110 \mathrm{kD}$ for $\mathrm{C} 23$ protein). An $80 \mathrm{kD}$ molecule has also recently been described and all of these can be identified immunologically. The nature and importance of these AgNORs is not fully known but they probably act as a regulator of rDNA transcription ${ }^{2}$ or maintain the extended configuration of $\mathrm{rDNA}^{3}{ }^{3}$ and they may represent ploidy or prove useful as a replicatory marker.

Whatever their precise nature, AgNORs have been observed for over a decade in chromosomal metaphase spreads and are best visualised using a silver colloid technique. They have previously been largely the province of cytogeneticists who have used them to identify certain trisomies using metaphase spreads at $60^{\circ} \mathrm{C}$. Recent modifications have, however, enabled a one step method to be applied to paraffin sections at $20^{\circ} \mathrm{C}$ without the previously troublesome background deposit. $^{4-6}$ Ploton et al $^{7}$ used this improved technique on an unspecified number of prostatic tissues stained as paraffin sections and suggested that AgNOR numbers reflect nuclear and cellular activity.

More recently the technique has been used in the investigation of certain human malignant tissues. Crocker and $\mathrm{Nar}^{1}$ applied it to non-Hodgkin's lymphomas and were able to distinguish between high and low grade. Crocker and Skilbeck ${ }^{8}$ applied it to melanocytic lesions of skin and found that naevocellular naevi and melanocarcinoma have different mean numbers of AgNORs. Egan and Smith' subsequently discovered that myoepithelial cells associated with in situ carcinoma had a mean of 2.5 AgNORs compared with a mean of 1.3 in benign breast tissue.

In this histochemical study we have shown that it is possible to distinguish benign fibrous proliferations of infancy from low grade fibrosarcoma on the basis of their relative numbers and distribution of AgNORs. The observed differences were significant $(p=0.01-$ 0.001 ). The inability to distinguish between the various types of fibromatoses may be explained by the relatively small numbers of each type or close ploidy.

Whatever the importance of the similarity of AgNOR numbers in fibrous proliferations and their dissimilarity in this respect from fibrosarcoma, in common with certain other human and malignant tissues, the enumeration of AgNORs is useful in the interpretation and diagnosis of fibrous proliferations of childhood.

\section{References}

1 Crocker J, Nar P. Nucleolar organiser regions in lymphomas. J Pathol 1987;151:111-8.

2 Olson MOJ, Thompson BA. Distribution of proteins among chromatin components of nucleoli. Biochemistry 1983;22: 3187-93.

3 Hernandez-Verdun Dd, Derenzini M, Bouteille M. Relationship between AgNOR proteins and ribosomal chromatin in situ during induced RNA synthesis inhibition. $J$ Ultrastruct Res 1984;88:55-65.

4 Howell W, Black DA. Controlled silver colloid staining of nucleolat organising regions with a protective colloidal developer: a one step method. Experentia 1980;36:1014.

5 Ploton D, Bobichon H, Adnet J. Ultrastructural localisation of nucleolar organising regions in nucleoli of human breast cancer cells using a one step staining method. Biol Cell 1982;43:229-32.

6 Ploton D, Menager M, Adnet J. Simultaneous high resolution localisation of nucleolar organising region protein and nucleo proteins in interphase and mitotic nuclei. Histochem $J$ 1984;16:897-906.

7 Ploton D, Menager M, Jeanesson P, et al. Improvement in the staining and visualization of argyrophilic proteins of the nucleolar organising regions at the optical level. Histochem $J$ 1986;18:5-14.

8 Crocker J, Skilbeck N. Nucleolar organiser region associated protein in melanocytic lesions of skin: a quantitative study. J Clin Pathol 1987;40:888-90.

9 Egan M, Smith K. Expression of S100 protein in breast lesions. J Clin Pathol 1987;40:1485-6.

Requests for reprints to: Dr M J Egan, Registrar in Histopathology, The Children's Hospital, Ladywood Middleway, Ladywood, Birmingham B16 8ET, England. 